\title{
EVALUASI PELAKSANAAN PENGELOLAAN SAMPAH DI BANK SAMPAH KECAMATAN SUKUN KOTA MALANG
}

\author{
Rachmat Ardiyan, Winarko, Demes Nurmayanti
}

\begin{abstract}
Solid waste to be have economic value after have been sorted and while good processed as already proved by trash bank in Malang city which invite the peoples to segregate the waste from it's source and come to the bank to make a deposit based on their waste's value. This research purposed to evaluate waste management implementation in Trash Bank of Malang city.

Method of this research according the data analysis included descriptive research nature with cross sectional approach. Object of this research in Malang Trash Bank is located in S. Supriyadi street number 38A on Sukun district of Malang city. Data taken subsequently will be analyzed descriptively based on tabulation of result from observation sheet and assessment sheet.

The results of this research showed that quantity of rubbish was accepted by Malang Trash Bank about $2500 \mathrm{Kg} /$ day and $75 \%$ majority rubbish source come from household type. Requirements of building's construction and trash bank of standard management taken from the result of assessment which had meeting the standard (92\%) of requirements refer in Regulation of State Minister of the Environment number 13/2012. Work's mechanism in Malang Trash Bank achieved good criteria (85,3\%). Supporting factors of waste management implementation was planned and executed.

It is suggested to the Malang Trash Bank is necessary to add number of worker and transportation vehicle for picking up rubbish from customers or delivery ready to sale rubbish to collector and industry. Make cooperation with figures people, cadre environment, or rubbish businessmen in community empowerment particularly process to separate rubbish and keep environment cleanliness.
\end{abstract}

\section{Keywords $\quad$ : Evaluation, Waste Management and Trash Bank}

\section{PENDAHULUAN \\ Latar Belakang}

Sampah dapat dikatakan sebagai masalah kultural yang dampaknya akan menyentuh segi yang lainnya. Mengelola sampah memang bukan persoalan mudah karena banyak hal yang perlu disiapkan seperti pentingnya dukungan bersama dari berbagai pihak, terutama pihak swasta dan masyarakat itu sendiri. Perbaikan terhadap sistem pengelolaan sampah perlu dilakukan untuk meminimalkan dampak negatif yang ditimbulkan.

Sampah akan terus diproduksi dan tidak pernah berhenti selama manusia tetap ada. Sampah sendiri merupakan salah satu bentuk konsekuensi dari adanya aktifitas manusia maupun alam yang belum memiliki nilai ekonomis. Sampah dapat bernilai ekonomi jika telah dipilah dan diolah dengan baik. (Tim Penulis Penebar Swadaya, 2011)
Permasalahan sampah semakin rumit ketika masyarakat khususnya di daerah perkotaan tidak mempunyai kepedulian untuk memisahkan dan memilah sampahnya yang semakin hari bertambah banyak. Karena mereka menyerahkan sepenuhnya tanggung jawab tersebut hanya kepada petugas kebersihan dan dinas kebersihan kota setempat.

Berdasarkan hasil observasi tiga tahun yang lalu sebelum didirikan bank sampah, di tempat tersebut merupakan salah satu tempat pembuangan sampah sementara (TPS) di Kecamatan Sukun. Kondisi TPS yang ada di sana sangat mengganggu dan meresahkan warga. Beberapa masalah yang sering ditemukan antara lain yaitu masalah bau busuk yang menyengat, asap dari pembakaran sampah, banyak dijumpai binatang penular penyakit seperti lalat, tikus, maupun nyamuk, serta mengganggu keindahan kota. Setelah 
berdirinya bank sampah di Kecamatan Sukun tersebut, kondisi TPS dirubah menjadi lebih baik dari sebelumnya. Keberadaan bank sampah tersebut dapat membantu perekonomian masyarakat dengan cara menabung sampahnya.

\section{Tujuan Penelitian}

Mengevaluasi pelaksanaan dan penerapan pengelolaan sampah di Bank Sampah Kecamatan Sukun Kota Malang.

\section{METODE PENELITIAN}

\section{Jenis Penelitian}

Berdasarkan jenisnya, penilitian ini bersifat deskriptif yaitu penelitian yang dilakukan dengan tujuan untuk menggambarkan atau mendeskripsikan tentang suatu keadaan secara objektif.

Penelitian ini dilakukan secara observasional dengan pendekatan cross sectional dimana variabel yang termasuk faktor risiko dan variabel yang termasuk efek diobservasi sekaligus pada waktu yang sama karena pengamatan hanya dilakukan pada satu waktu tertentu. (Notoatmodjo, 2010)

Menggambarkan dan mendeskripsikan penerapan sistem pengelolaan sampah yang telah dilakukan di bank sampah Kecamatan Sukun Kota Malang.
Variabel Penelitian

1. Jumlah Sampah Nasabah

2. Persyaratan Bank Sampah

a. Persyaratan kontruksi bangunan

b. Persyaratan standar manajemen

3. Mekanisme Kerja Bank Sampah

a. Penyerahan sampah ke bank sampah

b. Penimbangan sampah

c. Pencatatan

d. Pemilahan sampah

e. Pengolahan sampah

f. Pemasaran hasil

g. Bagi hasil penjualan sampah

4. Faktor Penunjang Manajemen

Pelaksanaan Bank Sampah

a. Peraturan dan landasan hokum

b. Perencanaan

c. Pengorganisasian

d. Pembiayaan

e. Peralatan pengolahan

f. Pelaporan evaluasi bank sampah

\section{HASIL PENELITIAN dan PEMBAHASAN}

1. Jumlah sampah yang diterima oleh bank sampah Malang setiap harinya sebesar $2500 \mathrm{Kg}$, mayoritas jumlah sampah di bank sampah Malang berasal dari jenis pemukiman atau rumah tangga $(75 \%)$ dan jumlah yang paling sedikit dari jenis non binaan atau lainnya $(1,2 \%)$.

Berikut grafik jumlah sampah yang ditabung menurut sumbernya :

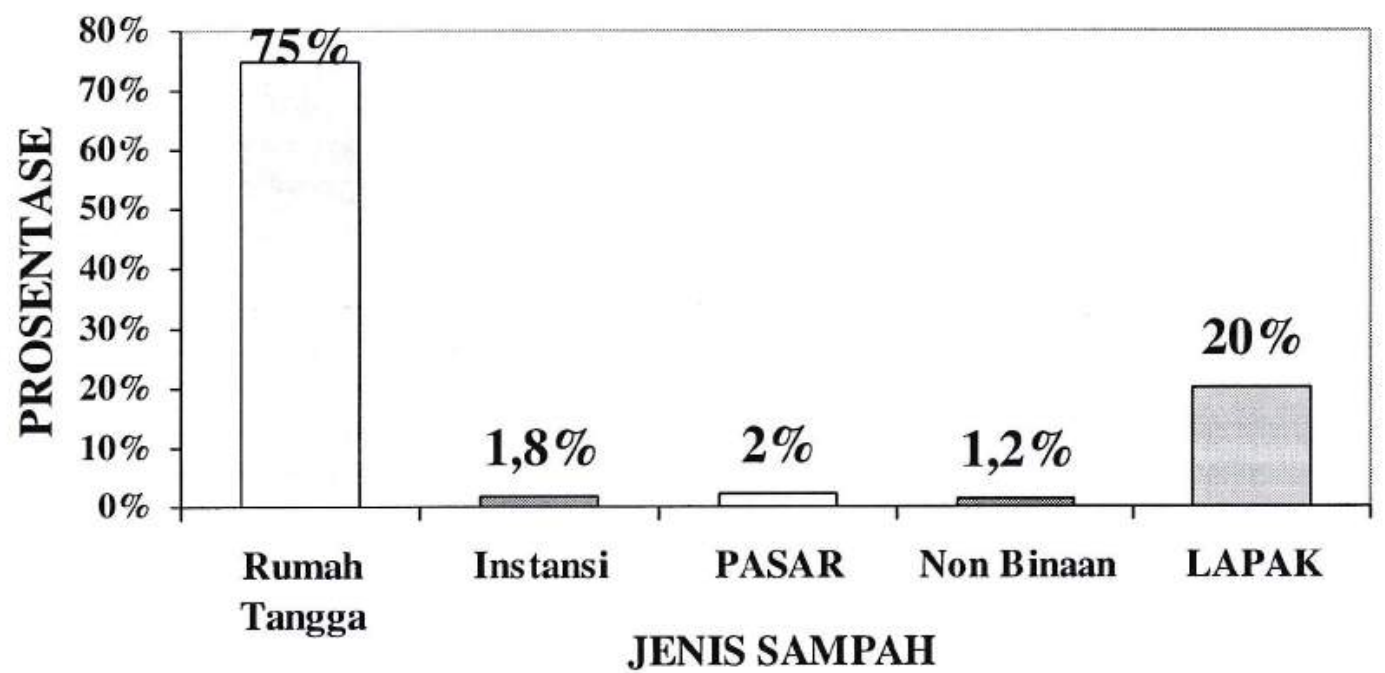

Menurut Sudrajat (2009) bahwa diperlukan luas area dan ketersediaan lahan yang mencukupi untuk mengelola sampah tersebut. Luas lahan Bank Sampah Malang yaitu $135 \mathrm{~m}^{2}$, sehingga luas yang tersedia dapat menampung sesuai kapasitas jumlah sampah yang diterima setiap harinya.

2. Hasil penilaian persyaratan kontruksi bangunan dan manajemen bank sampah Malang telah memenuhi standar dengan 
TABEL. 1

HASIL PENILAIAN PERSYARATAN BANK SAMPAH

\begin{tabular}{|c|c|c|c|c|c|}
\hline \multirow{2}{*}{ No } & \multirow{2}{*}{ Komponen Penilaian } & \multicolumn{2}{|c|}{ Hasil Obs. } & \multirow{2}{*}{$\begin{array}{c}\text { Prosentase } \\
(\%)\end{array}$} & \multirow{2}{*}{ Kriteria } \\
\hline & & Ya & Tidak & & \\
\hline 1. & Lantai & 8 & 0 & 100 & Baik \\
\hline 2. & Dinding & 5 & 0 & 100 & Baik \\
\hline 3. & Ventilasi (Alami) & 1 & 0 & 100 & Baik \\
\hline 4. & Atap & 3 & 0 & 100 & Baik \\
\hline 5. & Langit-langit & 4 & 0 & 100 & Baik \\
\hline 6. & Pintu Bank Sampah & 3 & 0 & 100 & Baik \\
\hline 7. & Lingkungan Bank Sampah & 17 & 2 & 89,5 & Baik \\
\hline 8. & Penabung Sampah & 4 & 1 & 80 & Baik \\
\hline 9. & Pelaksana Bank Sampah & 6 & 1 & 85,7 & Baik \\
\hline 10. & Pengepul / Pembeli Sampah & 4 & 0 & 100 & Baik \\
\hline 11. & Pengelolaan Sampah & 6 & 2 & 87,5 & Baik \\
\hline 12. & Peran Pelaksana Bank Sampah & 8 & 0 & 100 & Baik \\
\hline & Total & 69 & 6 & 93,3 & BAIK \\
\hline
\end{tabular}

Berdasarkan tabel di atas, menunjukkan bahwa kontruksi bangunan dan kondisi lingkungan sekitar bank sampah Malang telah memenuhi persyaratan. Hal tersebut disebabkan adanya biaya investasi awal yang berasal dari bantuan dana pemerintah kota setempat dan kerjasama pihak swasta lain seperti CSR PT. PLN Persero distribusi Jawa Timur. Sehingga mendukung proses mekanisme kerja serta manajemen pengelolaan sampah supaya terlaksana dengan baik dan lancar.

3. Proses mekanisme kerja di bank sampah Malang telah terlaksana dengan baik dan lancar karena didukung kontruksi bangunan dan standar manajemen bank sampah yang memenuhi syarat.

Berikut ini tabel hasil penilaian mekanisme kerja di bank sampah :

TABEL. 2

HASIL PENILAIAN MEKANISME KERJA BANK SAMPAH

\begin{tabular}{|c|c|c|c|c|c|}
\hline \multirow{2}{*}{ No } & \multirow{2}{*}{ Komponen Penilaian } & \multicolumn{2}{|c|}{ Hasil Obs } & \multirow{2}{*}{$\begin{array}{l}\text { Prosentase } \\
\text { (\%) }\end{array}$} & \multirow{2}{*}{ Kriteria } \\
\hline & & Ya & Tidak & & \\
\hline 1. & $\begin{array}{l}\text { Penyerahan Sampah ke Bank } \\
\text { Sampah }\end{array}$ & 8 & 2 & 80 & Baik \\
\hline 2. & Penimbangan Sampah & 2 & 0 & 100 & Baik \\
\hline 3. & Pencatatan & 4 & 0 & 100 & Baik \\
\hline 3. & Pemilahan Sampah & 2 & 1 & 66,7 & Cukup \\
\hline 4. & Pengolahan Sampah & 5 & 0 & 100 & Baik \\
\hline 5. & Pemasaran Hasil & 5 & 2 & 71,4 & Cukup \\
\hline 6. & Bagi Hasil Penjualan & 3 & 0 & 100 & Baik \\
\hline & Total & 29 & 5 & 85,3 & BAIK \\
\hline
\end{tabular}

Berdasarkan tabel tersebut, dapat diketahui bahwa hasil penilaian mekanisme kerja yang dilakukan di Bank Sampah Malang telah memenuhi syarat dengan kriteria baik $(85,3 \%)$ dan hanya 2 komponen penilaian yang kriterianya cukup yaitu : a. Hasil observasi menemukan beberapa petugas pemilahan yang belum memakai APD secara lengkap saat bekerja. Karena alat pelindung diri yang sering dipakai hanya masker.

b. Masalah yang ditemukan saat proses pemasaran hasil sampah yang siap dijual 
yaitu jumlah kendaraan terbatas dan sering menggunakan mobil sewaan untuk mengirim sampah jika jumlah pesanan pabrik terlalu banyak.

4. Faktor penunjang manajemen pelaksanaan bank sampah Malang telah terbentuk dan terlaksana dengan baik sesuai standar peraturan dan dasar hukum yang berlaku. Berikut ini pembahasannya yaitu :

a. Berdasarkan penelitian Damanhuri dan Padmi (2010), menyatakan bahwa peraturan yang diperlukan dalam penyelenggaraan sistem pengelolaan persampahan antara lain mengatur tentang :

1) Ketertiban umum yang terkait dengan penanganan sampah

2) Rencana induk pengelolaan sampah kota

3) Bentuk lembaga dan organisasi pengelola

4) Tata cara penyelenggaraan pengelolaan

5) Kerja sama dengan berbagai pihak terkait.

Bank Sampah Malang telah berbadan hukum koperasi dengan landasan hukum dari pengesahan Walikota Malang dan peraturan yang berlaku yaitu Peraturan Daerah Kota Malang No. 10 tahun 2010 tentang pengelolaan sampah. Berdasarkan peraturan tersebut telah memuat dan menyebutkan kebijakan dan strategi terkait bagaimana cara penanganan serta pengelolaan sampah di Kota Malang. Sehingga peraturan tersebut memenuhi syarat menjadi landasan hukum bagi Bank Sampah Malang.

b. Perencanaan awal yang dilakukan antara lain :

1) Melakukan survey untuk mendapatkan informasi tentang jenis sampah layak jual, fluktuasi harga sampah dan tempat penjualan hasil pengolahan sampah atau pemasaran.

2) Melakukan analisa hasil survey dengan analisa SWOT (Strenght, Weakness, Opputunity, and Threat) sehingga diharapkan pada saat mendirikan dan menjalankan Bank Sampah tersebut dapat menghindari terjadinya kemacetan proses pengelolaan.

Permasalahan yang ditemukan yaitu proses pemberdayaan masyarakat masih belum optimal, dapat dilihat dari sebagian besar nasabah BSM berasal dari golongan ekoriomi menengah ke bawah karena bagi mereka menjual sampah dapat menambah penghasilan. Sedangkan masyarakat golongan menengah ke atas mengganggap nilai jual sampah rendah dan tidak bersedia melakukan pemilahan sampah secara terorganisir.

c. Pengorganisasian di bank sampah Malang telah terorganisir dengan baik, yang dibuktikan dengan adanya struktur organisasi yang jelas. Permasalahan yang ditemukan yaitu jumlah tenaga kerja dinilai masih terbatas karena terdapat perangkapan tugas seperti bendahara dengan manajer pengambilan dan pemberdayaan yang dijabat oleh orang yang sama. Oleh karena itu, penambahan jumlah tenaga kerja sangat diperlukan untuk mengoptimalkan kinerja dan pengembangan bank sampah.

d. Pembiayaan di bank sampah Malang menggunakan modal awal dari dana hibah pemerintah setempat dan kerjasama dengan pihak swasta. Sedangkan penyusunan rencana anggaran dan laporan keuangan dilakukan setiap bulannya melalui software program komputer sistem informasi manajemen (SIM). Penetapan daftar harga tiap jenis sampah ditentukan menurut kesepakatan pengurus bank sampah Malang dan mengikuti harga pasar supaya tidak jauh berbeda dengan harga lapak.

e. Peralatan pengolahan yang digunakan yaitu :

1) Komposter untuk membuat kompos jumlahnya 2 buah drum.

2) Mesin pencacah untuk mencacah plastik berjumlah 2 buah.

3) Peralatan pembuatan biogas terdiri dari 3 buah drum dan 1 drum untuk pengumpulan gas yang dihasilkan.

Kemampuan peralatan yang dimiliki bank sampah Malang tahan lama dan telah diuji efektifitas karena memakai biaya pemeliharaan dan penyusutan setahun sekali. Kondisi peralatan selalu diperiksa setiap hari kerja sebelum digunakan. Untuk perbaikan peralatan memanggil bantuan teknisi dari luar. Pengoperasian alat berasal dari tenaga kerja bank sampah divisi produksi dan sesuai dengan prosedur kerja yang berlaku.

f. Pelaporan evaluasi bank sampah disusun berdasarkan hasil rekapitulasi laporan setiap divisi tentang penerimaan kas dari 
hasil penjualan, biaya tetap, biaya variabel dan biaya lain-lain. Laporan evaluasi juga membahas laporan kendala serta permasalahan yang ditemui dalam pelaksanaan bank sampah untuk mencari solusi yang tepat sehingga tidak mengecewakan nasabah.

\section{KESIMPULAN \& SARAN}

\section{Kesimpulan}

1. Dari hasil penelitian dapat diketahui jumlah rata-rata sampah yang diterima bank sampah Malang sekitar 2500 $\mathrm{Kg} / \mathrm{hari}$, sebagian besar jumlah sampah bersumber dari jenis rumah tangga atau pemukiman dengan prosentase $75 \%$ dan paling sedikit dari jenis non binaan dengan prosentase $1,2 \%$.

2. Telah memenuhi standar persyaratan kontruksi dan standar manajemen, mekanisme kerja baik, dan seluruh faktor penunjang manajemen pelaksanaan bank sampah di Bank Sampah Malang telah terencana dan dilaksanakan dengan baik.

\section{Saran}

1. Bagi Pihak Bank Sampah Malang

a. Penambahan jumlah tenaga kerja petugas pemilah dan pengambilan sangat diperlukan untuk mengoptimalkan kinerja dan pengembangan bank sampah.

b. Pelatihan dan sosialisasi pentingnya memakai APD seperti pemakaian masker dan sarung tangan terutama bagi petugas saat pemilahan sampah.

c. Jumlah kendaraan juga perlu ditambah lagi karena diperlukan untuk jasa pengambilan sampah dari nasabah dan pemasaran hasil sampah siap jual. Sehingga volume sampah yang diangkut tidak melebihi kapasitas kendaraan yang ada.

2. Bagi Pengelola Bank Sampah Lainnya

a. Melakukan kerja sama dengan para tokoh masyarakat, kader lingkungan, pemegang kebijakan pemerintah setempat dan para pelaku usaha persampahan lainnya untuk menggerakkan masyarakat memilah sampahnya dan menjaga kebersihan lingkungan.

b. Pengakaderan dan pemberdayaan dari segi masyarakat ekonomi menegah ke atas untuk menjadi nasabah sehingga ikut merasakan manfaat berdirinya bank sampah.

\section{DAFTAR PUSTAKA}

Damanhuri, Enri, dan Tri Padmi, 2010. Diktat Kuliah TL-3104: Pengelolaan Sampah. Program Studi Teknik Lingkungan Fakultas Teknik Sipil Lingkungan-ITB. Bandung. Edisi Semester I: 10.

Migristine, Ririn, 2009. Pengolahan Sampah Plastik. Bandung, Titian Ilmu. Edisi revisi: $1-7$,

Morgan, Sally, 2009. Daur Ulang Sampah. Solo, Tiga Serangkai. Cetakan1: 4-10.

Peraturan Menteri Pekerjaan Umum Nomor 21/PRT/M/2006 Tentang Kebijakan dan Strategi Nasional Pengembangan Sistem Pengelolaan Persampahan Tahun 2006.

Peraturan Daerah Kota Malang Nomor 10 Tahun 2010 Tentang Pengelolaan Sampah.

Permadi, A. Guruh, 2011. Menyulap Sampah Jadi Rupiah. Surabaya, Mumtaz Media. Cetakan Agustus 2011: vii, 6-8.

Peraturan Menteri Lingkungan Hidup Nomor 13 Tahun 2012 Tentang Pedoman Pelaksanaan 3R (reduce, reuse, recycle) melalui Bank Sampah.

Permanasari, Devina dan E. Damanhuri, 2010. Studi Efektivitas Bank Sampah Sebagai Salah Satu Pendekatan Dalam Pengelolaan Sampah Yang Berbasis Masyarakat. Program Studi Teknik Lingkungan-FTSL ITB Bandung. Hal 4-5.

Sudrajat, H. R, 2009. Mengelola Sampah Kota : Solusi Mengatasi Masalah Sampah Kota dengan Manajemen Terpadu dan Mengolahnya Menjadi Energi Listrik dan Kompos. Jakarta, Penebar Swadaya. Cetakan 3: 25.

Tim Penulis Penebar Swadaya, 2011. Penanganan dan Pengolahan Sampah. Jakarta, Penebar Swadaya. Cetakan 4: 3, 8-11. 